\title{
THE HÆMOLYTIC STREPTOCOCCUS AS A FACTOR IN THE CAUSATION OF ACUTE RHEUMATISM
}

\author{
H. J. GIBSON, M.B., D.P.H., W. A. R. THOMSON, M.B., and \\ D. STEWART, M.D., M.R.C.P.
(From the Departments of Bacteriology and Medicine, Edinburgh
University.)

Introduction.-The conception of acute rheumatism as a manifestation of, or sequel to, infection with the hæmolytic streptococcus has lately received much support.

Coburn (1931) has put forward clinical, epidemiological and bacteriological evidence of the causal relationship of this micro-organism. Perhaps the most striking results which he records are those of skin reactions on rheumatic and nonrheumatic subjects in which he used 'nucleo-protein' from a variety of bacteria. An association between infections of the upper respiratory tract and skin reactions to the homologous nucleo-protein could be demonstrated, and in cases of acute rheumatism the hæmolytic streptococcus appeared to be the important invader as judged by cutaneous allergy.

Previous to this Birkhaug (1927) and Kaiser (1928) had suggested infection with a well defined non-methæmoglobin-producing type of streptococcus as the cause of acute rheumatism and had applied skin-tests with filtrates of cultures of this organism. Irvine-Jones (1928), who noted similar skin reactions, was inclined to the view that streptococci were related to acute rheumatism though no one type of the micro-organism was incriminated. Mackenzie and Hanger (1927), on the other hand, after a study of allergic reactions to antigens of streptococci of different types could not correlate their findings with any previous or existing infections.

Schlesinger (1930) and others have recorded the frequent observation of acute nasopharyngeal infection, sometimes associated with hæmolytic streptococci, as having an apparently specific effect in activating latent rheumatism. Sheldon (1931) recorded an outbreak of epidemic relapse among rheumatic convalescents, the recrudescence of the rheumatic symptoms following tonsillitis after a latent period of one to three weeks. Of particular significance was his finding that febrile attacks following infection with other organisms (pneumococcus, B. influenzæ and M. catarrhalis) did not appear to influence the rheumatic state in any way. Collis (1931) proved that in this outbreak the throat infection preceding the relapse was due in all cases to the hæmolytic streptococcus and, on the lines of Coburn's work, showed a high percentage of rheumatic patients to be allergic when skin-tested with extracts of this micro-organism. Recently Todd (1932), approaching the problem from the immunological aspect, has shown that those suffering from acute rheumatism possess in their serum a higher concentration of anti-hæmolysin capable of neutralizing specifically the hæmolytic toxin of $S$. pyogenes than that in the serum of normal individuals. The presence of this anti-body is indirect evidence of previous infection with the hæmolytic streptococcus. A similar inference may be drawn from the results of Nicholls and Stainsby (1931) who demonstrated agglutinins for streptococci in a high proportion of cases of rheumatism. Suggestive results are reported in a recent paper by Collis and Sheldon (1932) who attempted desensitization of rheumatic 
children by intravenous vaccination with hæmolytic streptococci. They found that in presence of a persistent focus of infection in the throat the vaccine stimulated an apparently specific focal reaction in the pericardium and joints while in the absence of such a focus considerable clinical improvement followed the vaccination. In a proportion of cases which had previously given a positive reaction to hæmolytic streptococcus extract the reaction became negative after the vaccine course.

\section{Present investigations.}

The work here recorded is a study of cases of acute rheumatism in Edinburgh along lines similar to those employed by Collis and Sheldon in London. With the co-operation of physicians of various institutions in the city, cases have been examined bacteriologically, full clinical data recorded, and intradermal tests with extracts of numerous strains of streptococci of all types carried out. An equal number of non-rheumatic controls of the same age and in the same wards have been investigated in the same way.

Throat swabs.-Throat swabs were inoculated on horse-blood-agar plates within two hours of being taken. After 24 hours' incubation hæmolytic colonies were subcultured on to a further blood-agar plate. Single colonies from the second plate were inoculated on to a heated-blood-agar plate for observation of methæmoglobin production. In the absence of this a single colony was again picked off and transferred to a tube of Robertson's cookedmeat medium with liquid paraffin seal. In this medium the micro-organisms gave a profuse growth after 24 hours and could be stored in the dark at $-6^{\circ} \mathrm{C}$. for months without subculture. This medium was selected for the maintenance of cultures in preference to blood-broth because it could be sterilized by autoclaving, thus avoiding the risk of contamination inseparable from any medium containing fresh body-fluids. In addition the anærobic conditions and infrequent subculture tend to preserve the virulence, and probably also the serological characters, of the strain as isolated.

In all cases the production of hæmolysin for the red corpuscles of the horse in broth culture was estimated quantitatively, and all strains excluded if no such lysin could be demonstrated.

Bacterial extracts.-Streptococci from which extracts were made were grown for 24 hours in phosphate broth, $100 \mathrm{c.cm}$. of broth in large centrifuge tubes being employed. The micro-organisms were centrifuged and the supernatant broth removed. The sediment was washed twice in 0.85 per cent. sterile saline solution and once in sterile water. The final sediment in approximately $1 \mathrm{c.cm}$. of water was transferred to the flask of a bacterial ball-mill and dried. At first the vacuum desiccator was used, but a product of exactly the same quality was found to result if the micro-organisms were dried in air at $45^{\circ} \mathrm{C}$. for 18 hours. The dried micro-organisms were then ground by rotation of the mill for three days and two nights. The powder resulting was suspended in $10 \mathrm{c.cm}$. of sterile saline and heated at $60^{\circ} \mathrm{C}$. for 15 mintues in a water-bath. Rapid centrifuging was then employed to separate the bacterial debris and the supernatant fluid, after the addition of 0.5 per cent. phenol, was concentrated extract (H.S.E.) for use, after dilution, in the skin-tests. 
Standardization of extract preparations.-The nitrogen content of all extracts was estimated by the micro-Kjeldahl method, the results being shown in Table 1. As the dosage used throughout the tests was $0.2 \mathrm{c.cm}$. of a 1 in 100 dilution, the nitrogen content of each injection of the hæmolytic streptococcus preparation was $0.00028 \mathrm{mgrm}$. The comparable figure for the extracts used by Collis (1931) and Coburn (1931) was 0.0002 mgrm.

TABLE 1.

Nitrogen CONTENT OF VARIOUS EXTRACTS.

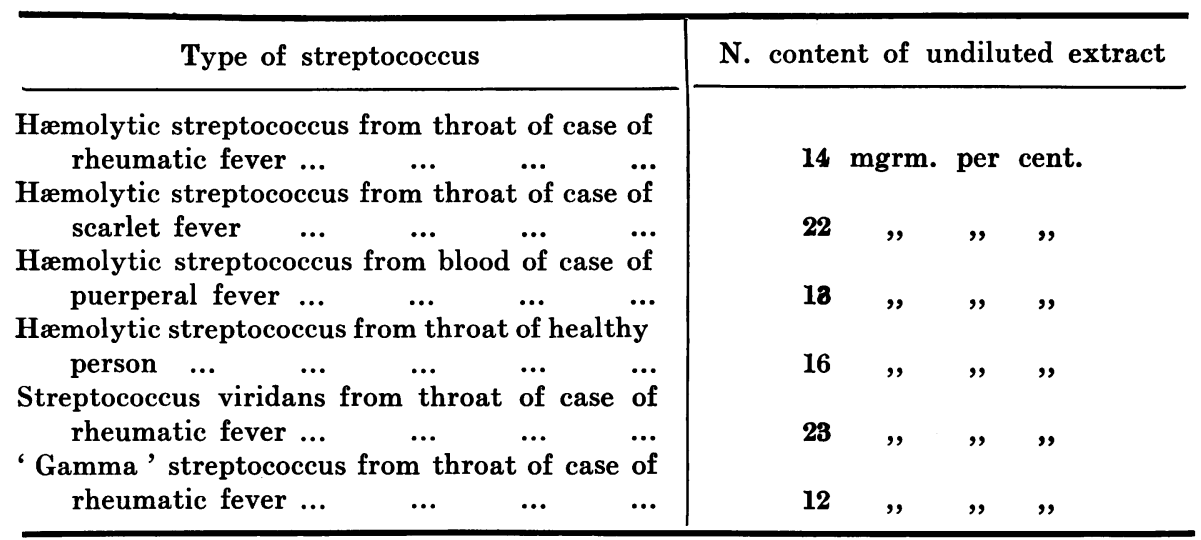

By the courtesy of Dr. Collis we were able to carry out simultaneous tests with his extract and our own in a series of 49 rheumatic and 15 nonrheumatic cases. The results, which it is unnecessary to give in detail, showed that 75 per cent. of the rheumatic cases and 87 per cent. of the non-rheumatic cases gave identical reactions. In the remaining cases in both groups the differences were only of degree and very slight. In no case was the reaction to Collis' extract positive when that to our own was negative, or vice versa. Our results and his may, therefore, be considered comparable.

Intradermal tests.-The volume of the appropriate dilution (usually 1 in 100) of all extracts injected into the skin was $0 \cdot 2 \mathrm{c.cm}$. A $1 \mathrm{c.cm}$. syringe and intradermal needle were used. In every patient at least 6 tests were made and 2 tests were done at one time, an interval of one day elapsing between each pair. Reagents used in the tests usually consisted of (1) and (2) extracts of different strains of hæmolytic streptococci, (3) extract of a viridans streptococcus, (4) extract of a 'gamma' streptococcus, (5) Dick toxin, (6) Dick ' control.'

Readings were made after 24 and 48 hours, two diameters at right angles being taken and also the diameter of the papular centre present in many of the more severe reactions. A note was also made of œdema and tenderness, if present, and the colour of the reaction.

As a rule only one set of observations was made on each patient, but when the duration of treatment in the ward permitted, the tests were all 
repeated at monthly intervals. With each set of tests throat swabs were repeated.

Strains from which extracts have been prepared included the following:-

(1) Strain of hæmolytic streptococcus from throat of a case of acute rheumatism. This extract was standardized by parallel tests performed along with an extract supplied by Dr. Collis as described. It has been used throughout and extracts of other hæmolytic streptococci have been tested in comparison with it. In the following tables all the results tabulated under the heading H.S.E. (hæmolytic streptococcus extract) are those obtained with this extract.

(2) Strain of hæmolytic streptococcus from a normal control throat.

(3) Strain of hæmolytic streptococcus from an early case of scarlet fever. (This was serologically typed by Dr. F. Griffith and found to be type II.)

(4) Strain of hæmolytic streptococcus freshly isolated from blood-culture in a case of puerperal septicæmia.

(5) Strain of streptococcus viridans isolated from the throat in a case of acute rheumatism.

(6) Strain of ' gamma' streptococcus isolated from the throat of a case of acute rheumatism. This strain was streptococcal in morphology, insoluble in bile and quite inert on fresh or heated blood-agar. It did not show the heat resistance $\left(60^{\circ}\right.$ C. -15 minutes) associated with the enterococcus. Unlike Birkhaug's (1927) streptococcus it did not ferment inulin.

Dick toxin and control were the commercial preparations of Burroughs Wellcome and Company, Limited.

\section{Results.}

In all 140 cases of acute rheumatism have been examined, together with 145 controls chosen as being of the same age, sex and environment as the rheumatic cases. A complete investigation could not be made on all owing in a few instances to removal from the wards soon after tests were commenced. Again throat swabs were frequently taken in rheumatic outpatients on whom it was not possible to carry out skin-tests. In other cases in the early stages of the work the throat swabs of cases were not taken at the time of the tests. A further source of apparent discrepancy in the totals recorded in the tables is that in the later stages where the H.S.E. and Dick reactions were both positive, serum neutralization tests were done which replaced the reactions with viridans and 'gamma' extract. These facts explain why the numbers appearing in the tables do not include the whole 140 cases and 145 controls. The results tabulated include all the data we have collected on each point in the investigation, and no selection of available material has been made for this report. 
The skin reaction to extract of hæmolytic streptococci.-At the outset we were able to verify the findings of Coburn (1931), Collis (1931) and others, that the soluble products of ground streptococci produced a well-defined reaction when injected into the skin of certain individuals. Appearing in from 6 to 12 hours, an area of erythema gradually increased in size and attained its maximum in 36 hours, when it slowly faded. Swelling was present in all the more marked reactions, sometimes diffuse over the whole red area, but more usually concentrated in an area of 10 to $18 \mathrm{~mm}$. diameter in the centre. This central papule was invariably tender and of a deeper red than the peripheral zone. The maximum diameter of the reaction varied enormously from the weak or doubtful positive of $12 \mathrm{~mm}$. to a large area attaining a diameter of $120 \mathrm{~mm}$. or more. General symptoms were not as a rule noted. In a group of medical students tested, a small number complained of headache, dizziness and in one case vomiting which appeared 4 hours after the test injections. Mackenzie and Hanger (1927) reported similar general reactions which were more frequent in adults than in children. Apart from this group of medical students, however, with perhaps one exception, such systemic disturbances were never detected.

TABLE 2.

EXTRACT OF HæMOLYTIC STREPTOCOCCUS (FROM THROAT OF RHEUMATIC CASE) : RESULTS OF INTRADERMAL REACTIONS IN 140 CASES OF ACUTE RHEUMATISM AND 145 CONTROLS.

\begin{tabular}{|c|c|c|c|c|c|c|c|}
\hline \multirow[t]{2}{*}{ Group } & \multirow[t]{2}{*}{ Total } & \multicolumn{2}{|c|}{$\begin{array}{c}\text { Weak positive } \\
\text { 12-19 mm. mean } \\
\text { diameter }\end{array}$} & \multicolumn{2}{|c|}{$\begin{array}{c}\text { Strong positive } \\
\text { Over } 20 \text { mm. mean } \\
\text { diameter } \\
\end{array}$} & \multicolumn{2}{|c|}{ Negative } \\
\hline & & Total & Percentage & Total & Percentage & Total & Percentage \\
\hline Rheumatic & 140 & 18 & 12 & 89 & 64 & 33 & 24 \\
\hline Control & 145 & 31 & 20 & 50 & 35 & 64 & 45 \\
\hline
\end{tabular}

Incidence of positive reactions in rheumatic and control groups.-Table 2 classifies the results of skin tests in rheumatic and control groups as weak positive, strong positive and negative. It will be noted that the most significant difference between the two groups was shown by the strong positive reactions where the rheumatic group showed a rate of 64 per cent. as compared with 35 per cent. in controls. It is noteworthy that the weaker reactions were more common in controls than in cases of rheumatism. The results we obtained were on the whole similar to those of Collis (1932) who showed that 25 per cent. of cases of rheumatism gave negative results to H.S.E. (as compared with our 24 per cent.), while 28 per cent. of nonrheumatic controls reacted strongly to the extract (as compared with 35 per cent. in our series). Extracts of other hæmolytic streptococci from cases 
of scarlet fever, puerperal fever and normal control throats have been used in parallel with the extract of the rheumatic strain in a number of individuals. Except that some extracts were consistently rather stronger than others, there was a remarkable agreement among the results with hæmolytic strains. The skin-reacting factor appeared to be common to many if not all strains of hæmolytic streptococci.

It was noted that the positive skin reactions obtained in cases at one hospital (the Astley Ainslie Institution) were larger and more frequent than in the other hospitals. This institution for convalescents receives many old-standing ear, nose and throat cases of which many were doubtless of hæmolytic streptococcal origin. Table 3 indicates the results in the group

TABLE 3.

INCIDENCE OF POSITIVE REACTIONS AND SIZE OF REACTIONS IN RHEUMATIC AND CONTROL GROUPS COMPARED IN (A) A CONVALESCENT INSTITUTION, AND (B) ALL OTHER HOSPITALS WHERE PATIENTS WERE STUDIED.

\begin{tabular}{l|c|c|c|c|c|c}
\hline \multirow{2}{*}{ Group } & \multicolumn{3}{|c|}{ Convalescent institution } & \multicolumn{3}{c}{ Other hospitals } \\
\cline { 2 - 7 } & Total & $\begin{array}{c}\text { Percentage } \\
\text { strongly } \\
\text { positive to } \\
\text { H.S.E. }\end{array}$ & $\begin{array}{c}\text { Mean } \\
\text { diameter } \\
\text { of H.S.E. } \\
\text { reaction }\end{array}$ & Total & $\begin{array}{c}\text { Percentage } \\
\text { strongly } \\
\text { positive to } \\
\text { H.S.E. }\end{array}$ & $\begin{array}{c}\text { Mean } \\
\text { diameter } \\
\text { of H.S.E. } \\
\text { reaction }\end{array}$ \\
\hline Rheumatic & 18 & 89 & $36.34 \mathrm{~mm}$. & 64 & 59 & $20 \cdot 47 \mathrm{~mm}$. \\
Control & 21 & 81 & $31.29 \mathrm{~mm}$. & 110 & 31 & $13 \cdot 29 \mathrm{~mm}$. \\
\hline
\end{tabular}

of rheumatics and controls which were tested there, and for comparison the results obtained at other institutions over the same period of time are included. It will be seen that the proportion of positive reactors, 89 per cent. and 81 per cent. for rheumatic and control groups respectively, is much above the percentages recorded elsewhere (59 per cent. and 31 per cent.). In addition the severity of reactions, indicated by the mean diameter for all cases was much higher in the special convalescent hospital group. It will be seen that the percentage of positives and the mean diameter of reactions in the non-rheumatics of this institution are both greater than those in rheumatic cases elsewhere. The further significant fact was elicited that of the 16 cases of quiescent rheumatism in the Astley Ainslie Institution who gave strongly positive extract reactions, 8 were harbouring hæmolytic streptococci in the throat. No relapses occurred in these during three months of observation.

Streptococcus viridans has been associated with many theories of the ætiology of acute rheumatism. On the assumption that an allergic skin reaction to the extract of such a streptococcus might be an index of previous infection, all cases were tested as described with such an extract, 
The results recorded in Table 4 show that no significant difference existed between the two groups in their reactions to this extract.

TABLE 4.

EXtract OF Viridans STREPTOCOCCUS (From throat OF RHEUMatic CASE) : RESUlts OF INTRADERMAL REACTIONS IN 120 CASES OF ACUTE RHEUMATISM AND 131 cONTROLS.

\begin{tabular}{|c|c|c|c|c|c|c|c|}
\hline \multirow{3}{*}{ Group } & \multirow{3}{*}{ Total } & \multirow{2}{*}{\multicolumn{2}{|c|}{$\begin{array}{c}\text { Weak positive } \\
\begin{array}{c}\text { 12-19 mm. mean } \\
\text { diameter }\end{array}\end{array}$}} & \multirow{2}{*}{\multicolumn{2}{|c|}{$\begin{array}{c}\text { Strong positive } \\
\begin{array}{c}\text { Over } 20 \mathrm{~mm} . \text { mean } \\
\text { diameter }\end{array} \\
\end{array}$}} & \multirow{2}{*}{\multicolumn{2}{|c|}{ Negative }} \\
\hline & & & & & & & \\
\hline & & Total & Percentage & Total & Percentage & Total & Percentage \\
\hline Rheumatic & 120 & 18 & 15 & 33 & 27 & 69 & 58 \\
\hline Control & 131 & 27 & 21 & 32 & 24 & 72 & $\mathbf{5 5}$ \\
\hline
\end{tabular}

Similarly in Table 5 are shown the results obtained with extract of ' gamma' type streptococcus. Especially significant in this case is the similarity between rheumatic and control groups in the percentage of negative reactions. The differentiation of weak from strong positive reactions is arbitrary, but of more significance is the sum of all reactions which shows no difference between the two groups.

TABLE 5.

EXTRACT OF INERT 'GAMma' STREPTOCOCCUS : RESUlts OF INTRADERMaL REACTIONS IN 122 CASES OF ACUTE RHEUMATISM AND 131 CONTROLS.

\begin{tabular}{c|c|c|c|c|c|c|c}
\hline \multirow{3}{*}{ Group } & Total & \multicolumn{2}{|c|}{$\begin{array}{c}\text { Weak positive } \\
\text { diameter }\end{array}$} & \multicolumn{2}{|c|}{$\begin{array}{c}\text { Strong positive } \\
\text { diam }\end{array}$} & \multicolumn{2}{|c}{ Negative } \\
& & $\begin{array}{c}\text { Total } \\
\text { diameter }\end{array}$ & Percentage & Total & Percentage & Total & Percentage \\
\hline Rheumatic & 122 & 16 & 12 & 26 & 21 & 80 & 67 \\
Control & 131 & 24 & 18 & 22 & 17 & 85 & 65 \\
\hline
\end{tabular}

While no apparent relationship could be established between the non-hæmolytic streptococci and acute rheumatism by the intradermal reaction, there was some evidence that allergic reactivity to H.S.E. was not entirely independent of that to the non-hæmolytic types.

All rheumatics and controls who had been tested simultaneously with extracts of all three types of streptococcus were grouped according to the intensity of reaction to H.S.E. (strong positive, weak positive and negative). It was then possible to determine the percentage of positive 
reactors to extracts of viridans and ' gamma'-type streptococci respectively in each of these groups. Apart from its relationship to acute rheumatism, the presence of allergy to H.S.E. appeared to increase the probability of allergy to products of non-hæmolytic streptococci being present. Table 6 shows that in presence of a strongly positive reaction to H.S.E., 62 per cent. of all individuals (cases and controls) react to extract of $S$. viridans while only 17 per cent. of those failing to react to H.S.E. reacted to extract of S. viridans or ' gamma' streptococci. The general tendency in both rheumatic and control groups is for the reactivity to the non-hæmolytic streptococcal extract to be less as the intensity of reaction to H.S.E. declines.

\section{TABLE 6.}

60 RHEUMATIC AND 80 CONTROL CASES GROUPED ACCORDING TO THE INTENSITY OF REACTION to H.S.E. InCIDENCE of POSITIVe ReActions to EXTRACTS OF viridans and 'Gamma' STREPTOCOCCI IN EACH GROUP.

\begin{tabular}{|c|c|c|c|c|c|c|c|c|}
\hline \multirow[b]{3}{*}{$\begin{array}{r}\text { Group giving strong } \\
\text { positive reactions to } \\
\text { H.S.E. (over } 20 \mathrm{~mm} \text {.) }\end{array}$} & \multirow[b]{3}{*}{$\begin{array}{l}\text { Rheumatics } \\
\text { Controls } \\
\text { Rheumatics } \\
\text { and controls }\end{array}$} & \multirow[b]{3}{*}{$\begin{array}{l}\text { (39) } \\
(40) \\
(79)\end{array}$} & \multicolumn{6}{|c|}{$\begin{array}{l}\text { Percentage of strongly positive reactions } \\
\text { to extracts of non-hæmolytic streptococci }\end{array}$} \\
\hline & & & \multicolumn{3}{|c|}{ Viridans type } & \multicolumn{3}{|c|}{ 'Gamma' type } \\
\hline & & & $\begin{array}{l}67 \\
58 \\
\\
62\end{array}$ & $\begin{array}{l}\text { per } \\
, " \\
, "\end{array}$ & $\begin{array}{c}\text { cent. } \\
\text { " } \\
\text { " }\end{array}$ & $\begin{array}{l}49 \\
37 \\
43\end{array}$ & $\begin{array}{l}\text { per } \\
\text {, } \\
,\end{array}$ & $\begin{array}{c}\text { cent. } \\
\text {, }\end{array}$ \\
\hline $\begin{array}{r}\text { Group giving weakly } \\
\text { positive reactions to } \\
\text { H.S.E. (12-20 mm.) }\end{array}$ & $\begin{array}{l}\text { Rheumatics } \\
\text { Controls } \\
\text { Rheumatics } \\
\text { and controls }\end{array}$ & $\begin{array}{l}\text { (11) } \\
\text { (17) }\end{array}$ & $\begin{array}{l}\mathbf{3 3} \\
\mathbf{3 5} \\
\\
\mathbf{3 4}\end{array}$ & $\begin{array}{l}\text { ", } \\
\text { ", }\end{array}$ & ", & $\begin{array}{l}11 \\
41\end{array}$ & ", & ", \\
\hline $\begin{array}{l}\text { Group giving nega- } \\
\text { tive reaction to } \\
\text { H.S.E. }\end{array}$ & $\begin{array}{l}\text { Rheumatics } \\
\text { Controls } \\
\text { Rheumatics } \\
\text { and controls }\end{array}$ & $\begin{array}{l}\text { (10) } \\
\text { (23) }\end{array}$ & $\begin{array}{l}20 \\
18\end{array}$ & ", & ", & $\begin{array}{l}20 \\
14\end{array}$ & ", & $"$ \\
\hline
\end{tabular}

This association may be due to the presence of a protein constituent common to hæmolytic and non-hæmolytic streptococci as shown by Lancefield (1928).

Age and the allergic skin reaction to H.S.E.-Collis (1932) recorded the interesting fact that in his series the age period 12-14 was that of maximum sensitivity and that no increase in incidence of reactors was observed in higher age periods. Derick and Fulton (1931) after a study of cutaneous reactions to a purified hæmolytic streptococcus nucleo-protein preparation in 670 cases also noted 15 years as the age up to which the proportion of positive reactors increased. They stated after 15, age played no part in determining the presence or absence of sensitiveness. Table 7 summarizes our results as they relate to this question. Features of the table are the high incidence of reactions ( 90 per cent.) in the age period 10-15 years with 
the fall to 68 per cent. in the over 15 group: also the curve of controls follows the same lines as that of cases in that no rise occurs over 15 years. The viridans and 'gamma' extract reactions also show the same fall after the 10-15 age-group. Collis (1932) recorded that if the figures were corrected to allow for the interval since the last acute attack, the differences referable to age itself were slight. We have not sufficient data to give any opinion on this point except to state that our ' over $15^{\prime}$ group was largely composed of adult patients in a general hospital, all being under treatment for a primary attack or recurrence of the disease. It would appear, therefore, that even in presence of active disease the age group including adult patients yields a smaller proportion of reactors than the age group 10-15.

TABLE 7 .

Age faCtor INFLUENCING SKIN REACTIONS To EXTRACTS OF STREPTOCOCCI OF DIFFERENT TYPES. BASED ON A SERIES OF 77 CONSECUTIVE RHEUMATIC CASES AND 88 CONTROLS.

\begin{tabular}{|c|c|c|c|c|}
\hline \multirow{2}{*}{$\begin{array}{l}\text { Streptococcus } \\
\text { extract }\end{array}$} & \multirow{2}{*}{ Groups } & \multicolumn{3}{|c|}{ Percentage positive* reactions in 3 age groups } \\
\hline & & 5-9 yr. & 10-15 yr. & Over $15 \mathrm{yr}$. \\
\hline Hæmolytic & $\left\{\begin{array}{l}\text { Rheumatic } \\
\text { Control }\end{array}\right.$ & $\begin{array}{l}46 \\
35\end{array}$ & $\begin{array}{l}90 \\
66\end{array}$ & $\begin{array}{l}68 \\
66\end{array}$ \\
\hline Viridans & $\left\{\begin{array}{l}\text { Rheumatic } \\
\text { Control }\end{array}\right.$ & $\begin{array}{l}56 \\
40\end{array}$ & $\begin{array}{l}61 \\
43\end{array}$ & $\begin{array}{l}46 \\
19\end{array}$ \\
\hline 'Gamma' & $\left\{\begin{array}{l}\text { Rheumatic } \\
\text { Control }\end{array}\right.$ & $\begin{array}{l}19 \\
37 \\
\end{array}$ & $\begin{array}{l}56 \\
34\end{array}$ & $\begin{array}{l}38 \\
25\end{array}$ \\
\hline
\end{tabular}

* Strong reactions only are included. When weak positive reactions are added the relative incidence as between one age group and another is maintained. The number in each group on which the above percentages are based ranged from 21 to 43 cases or controls.

Not only the proportion of reactors but also the severity of reactions was greater at the age period 10-15 years. This could be demonstrated by taking the mean of the diameters of all reactions to H.S.E. in each age group (see Table 8). This table shows the surprising fact that in the age group 5-9 years the average diameter of reactions in controls is exactly equal to that in rheumatic cases.

TABLE 8.

Mean diameter of Reactions to H.S.E. in RHEUmatic and CONTROL groups at THREE AGE PERIODS.

\begin{tabular}{|c|c|c|c|c|c|c|}
\hline \multirow[b]{2}{*}{ Group } & \multicolumn{2}{|c|}{ 5-9 years } & \multicolumn{2}{|c|}{ 10-15 years } & \multicolumn{2}{|c|}{ Over 15 years } \\
\hline & Total & $\begin{array}{c}\text { Mean } \\
\text { diameter }\end{array}$ & Total & $\begin{array}{c}\text { Mean } \\
\text { diameter }\end{array}$ & Total & $\begin{array}{c}\text { Mean } \\
\text { diameter }\end{array}$ \\
\hline Rheumatic & 22 & $18 \cdot 18 \mathrm{~mm}$. & 21 & $35.90 \mathrm{~mm}$. & 31 & $21.58 \mathrm{~mm}$. \\
\hline Controls & 38 & $18 \cdot 18 \mathrm{~mm}$. & 20 & $30 \cdot 20 \mathrm{~mm}$. & 21 & $20.33 \mathrm{~mm}$. \\
\hline
\end{tabular}


Clinical type of rheumatism and its relation to the results of skin reactions.-Three convenient clinical subdivisions were used for the classification of the cases of our rheumatic series. A febrile group was composed of those showing fever at the time of the test or during the preceding four weeks. The afebrile group were those cases of carditis more definitely subacute or chronic who had been afebrile for at least one month before the test. The cases of chorea constituted the third group.

Table 9 records the results. The following facts were noteworthy: (1) only the H.S.E. reaction appeared to be influenced to any marked extent by the clinical type of disease; (2) the febrile cases showed approximately only half the incidence of positives found in the chorea group (90 per cent.); (3) the afebrile group occupied a position midway between the febrile and chorea groups.

\section{TABLE 9.}

INCIDENCE OF SKIN REACTIONS TO EXTRACTS OF HEMOLYTIC, VIRIDANS AND 'GAMMA'

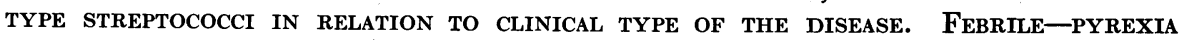
PRESENT AT TIME OF TEST OR DURING PRECEDING FOUR WEEKS. AFEBRILE-NO PYREXIA WITHIN FOUR WEEKS BEFORE TEST.

\begin{tabular}{|c|c|c|c|c|c|c|c|c|c|c|c|c|}
\hline \multirow[t]{2}{*}{ Clinical type } & \multicolumn{4}{|c|}{$\begin{array}{l}\text { Reaction to extract of } \\
\text { hæmolytic strep. }\end{array}$} & \multicolumn{4}{|c|}{$\begin{array}{l}\text { Reaction to extract of } \\
\text { viridans strep. }\end{array}$} & \multicolumn{4}{|c|}{$\begin{array}{l}\text { Reaction to extract of } \\
\text { 'Gamma' strep. }\end{array}$} \\
\hline & Total & + & \pm & 一 & Total & + & \pm & 一 & Total & + & \pm & - \\
\hline $\begin{array}{l}\text { Febrile } \\
\text { per cent. }\end{array}$ & 28 & $\begin{array}{l}13 \\
47\end{array}$ & 7 & $\begin{array}{r}8 \\
29\end{array}$ & 20 & $\begin{array}{r}8 \\
40\end{array}$ & 4 & $\begin{array}{r}8 \\
40\end{array}$ & 20 & $\begin{array}{r}7 \\
35\end{array}$ & 3 & $\begin{array}{l}10 \\
50\end{array}$ \\
\hline $\begin{array}{l}\text { Afebrile } \\
\text { per cent. }\end{array}$ & 33 & $\begin{array}{l}24 \\
73\end{array}$ & 4 & $\begin{array}{r}5 \\
15\end{array}$ & 28 & $\begin{array}{l}17 \\
61\end{array}$ & 5 & $\begin{array}{r}6 \\
21\end{array}$ & 28 & $\begin{array}{l}11 \\
39\end{array}$ & 6 & $\begin{array}{l}11 \\
39\end{array}$ \\
\hline $\begin{array}{l}\text { Chorea } \\
\text { per cent. }\end{array}$ & 19 & $\begin{array}{l}17 \\
90\end{array}$ & 1 & $\begin{array}{l}1 \\
5\end{array}$ & 15 & $\begin{array}{r}7 \\
47\end{array}$ & 5 & $\begin{array}{r}3 \\
20\end{array}$ & 15 & $\begin{array}{r}5 \\
33\end{array}$ & 3 & $\begin{array}{r}7 \\
47\end{array}$ \\
\hline
\end{tabular}

+ signifies skin reaction of $20 \mathrm{~mm}$. mean diameter or more.

$\pm \quad, \quad, \quad, \quad, 12-19 \mathrm{~mm}$. mean diameter.

- , , , , , less than $12 \mathrm{~mm}$. mean diameter.

An analysis of the influence of the time elapsing between the onset of illness and the test upon the sensitivity to the hæmolytic streptococcus extract showed that as this time interval increased so did the percentage of positive reactors (Table 10). This, however, appeared to be almost entirely due to the fact that the percentage of febrile cases decreased as the time interval lengthened. It was found impossible to show any direct relationship between the number of recurrences and the skin reactions, 
TABLE 10.

INTERVAL BETWEEN ONSET OF RHEUMATIC INFECTION AND TIME OF SKIN TEST, AS INFLUENCING TYPE OF REACTION TO HAMOLYTIC STREPTOCOCCUS EXTRACT.

\begin{tabular}{|c|c|c|c|c|}
\hline & Less than 1 month & 1-3 months & 4-6 months & Over 6 months \\
\hline Total cases & 18 & 16 & 10 & 15 \\
\hline $\begin{array}{l}\text { Strong } \\
\quad \text { positive }\end{array}$ & $\mathbf{9}=\mathbf{5 0} \%$ & $7=65 \%$ & $7=70 \%$ & $14=93 \%$ \\
\hline $\begin{array}{l}\text { Weak } \\
\quad \text { positive }\end{array}$ & $3=17 \%$ & $4=16 \%$ & $\mathbf{2}=\mathbf{3 0} \%$ & none \\
\hline Negative & $6=33 \%$ & $5=19 \%$ & $1=10 \%$ & $1=7 \%$ \\
\hline
\end{tabular}

Sore throats. Of 66 cases, 31 gave a history of sore throats. In 16 cases a history was obtained of the date of the last attack, and of these 3 had had an attack of tonsillitis 2-3 weeks before the onset of rheumatic pains, and 2 of them had attacks after admission to hospital. Table 11 shows that a larger number of those with a history of tonsillitis gave a positive reaction to the hæmolytic streptococcus extract than those with no such history.

TABLE 11.

SHOWING RELATION BETWEEN OCCURRENCE OF SORE THROAT AND TYPE OF REACTION TO HAMOLYTIC STREPTOCOCCUS EXTRACT.

\begin{tabular}{l|c|c|c|c}
\hline & No. of cases & Strong positive & Weak Positive & Negative \\
\cline { 2 - 3 } $\begin{array}{c}\text { History of } \\
\text { sore throat }\end{array}$ & 31 & $20=65 \%$ & $7=22 \%$ & $4=13 \%$ \\
$\begin{array}{c}\text { No history of } \\
\text { sore throat }\end{array}$ & 35 & $\mathbf{1 7}=49 \%$ & $\mathbf{9 = 2 5 \cdot 5} \%$ & $\mathbf{9 = 2 5 \cdot 5} \%$ \\
\hline
\end{tabular}

Tonsillectomy. Of the 74, cases of which clinical notes are obtainable, 11 had had the tonsils removed, in 2 cases the operation being performed after the skin tests had been carried out. Of the remaining 9,7 gave positive skin reactions, and 2 a weakly positive reaction. Two of these cases underwent the operation after admission to hospital, one 25 days, and the other 26 days before the skin tests were carried out, and both gave strongly positive reactions.

SCARLET FEver. Of 63 cases, 9 (11 per cent.) had had scarlet fever; of these, 3 gave positive, 4 weakly positive and 2 negative reactions. 
Dick reaction in acute rheumatism.-The Dick test was performed on every case of rheumatism and every control. Table 12 records the results, showing that the incidence of positives (16 per cent.) was unduly low in the rheumatic group. The finding of 28 per cent. as the Dick positive rate in controls is more normal. In an attempt to estimate how far a previous infection with hæmolytic streptococci has been operative in the causation of acute rheumatism the Dick test would appear to be a valuable guide. The presence of a positive Dick reaction does not however preclude the possibility of a previous infection with hæmolytic streptococci.

TABLE 12.

Results of Dick test CaRried out on 142 CASES OF ACUTE RHEUMatism AND 141 CONTROLS.

\begin{tabular}{l|c|c|c|c|c}
\hline \multirow{2}{*}{ Group } & Total & \multicolumn{2}{|c|}{ Positive } & \multicolumn{2}{c}{ Negative } \\
\cline { 3 - 6 } & & Total & Percentage & Total & Percentage \\
\hline Rheumatic & 142 & 23 & 16 & 119 & 84 \\
Control & 141 & 40 & 28 & 101 & 72 \\
\hline
\end{tabular}

Throat swab examinations. - Investigation of the throat yielded hæmolytic streptococci in 46 out of 107 rheumatic cases, and in 23 out of 116 controls. The percentages of individuals harbouring these microorganisms are thus 43 and 20 respectively. The micro-organisms are being maintained and studied further, especially with a view to determining whether any serological relationships can be demonstrated.

Table 13 and Table 14 show the results in an attempt to ascertain whether the finding of hæmolytic streptococci in the throat could be correlated in any way with the results of streptococcus extract and Dick reactions. It was thought possible that those in the rheumatic group, in the presence of the micro-organism, might have shown more tendency to develop the allergic reaction than the controls. This was not so, 83 per cent. of rheumatics and 95 per cent. of controls being positive to H.S.E. in presence of the hæmolytic streptococci (Table 13). Again, where hæmolytic streptococci were not isolated the results were very similar in the two groups.

TABLE 13.

CORRELATION OF RESULTS OF SKIN REACTIONS TO EXTRACT OF HÆMOLYTIC STREPTOCOCCUS WITH THE FINDING OF THAT MICRO-ORGANISM IN THE THROAT SWAB.

\begin{tabular}{c|c|c|c|c}
\hline Group & Total cases & $\begin{array}{c}\text { Hæmolytic } \\
\text { streptococcus } \\
\text { isolated in }\end{array}$ & $\begin{array}{c}\text { Percentage giving positive H.S.E. } \\
\text { skin reaction* }\end{array}$ & $\begin{array}{c}\text { Positive swab } \\
\text { Negative swab }\end{array}$ \\
\hline Rheumatic & 77 & 52 & 83 & 81 \\
Control & 81 & 25 & 95 & 71 \\
\hline
\end{tabular}

* All reactions over $12 \mathrm{~mm}$. diameter are included. 
The same facts in relation to the Dick test are given in Table 14. Again no significant differences in Dick reactivity are associated with the finding of hæmolytic streptococci in the throat. The table shows the rather striking fact that 22 per cent. and 15 per cent. of cases and controls respectively were Dick-positive while carrying a hæmolytic streptococcus in the throat.

TABLE 14.

Correlation of Results of Dick reaction with the finding of hemolytic STREPTOCOCCI IN THE THROAT SWAB.

\begin{tabular}{c|c|c|c|c}
\hline \multirow{2}{*}{ Group } & Total cases & $\begin{array}{c}\text { Percentage in } \\
\text { which hæmolytic } \\
\text { streptococci } \\
\text { isolated }\end{array}$ & Positive swab & Negative swab \\
\hline Rheumatic & 75 & 48 & 22 & 31 \\
Control & 82 & 24 & 15 & 19 \\
\hline
\end{tabular}

Absence of toxigenicity, or low invasive powers of the micro-organism, or alternatively a high tissue resistance of the patient, might readily account for these results.

\section{Discussion.}

Our work does not add much support to the allergic theory of acute rheumatism. At the outset we are faced by two sets of phenomena which may or may not be associated:-(1) Those referable to infection with the hæmolytic streptococcus which may quite well exist without any symptoms of acute rheumatism. Among these may be placed the finding of hæmolytic streptococci in the throat before or during an attack, the allergic reaction (shown by Gibson and McGibbon (1932) to develop in a high proportion of cases of non-rheumatic hæmolytic streptococcal infection, e.g., scarlet fever), the tendency towards a Dick-negative state and the presence of antistreptolysin in the serum as shown by Todd (1932). These may occur in the absence of any suggestion of rheumatism, and one or more are probably inseparably associated with all hæmolytic streptococcal infection. (2) Those referable to acute rheumatism, polyarthritis, carditis, chorea, etc.

Evidence associating the infection with the rheumatic state is to be found in the observation of epidemic rheumatic relapse superimposed on throat infection with hæmolytic streptococci. In assessing the value of the present work it must be borne in mind that no claim has ever been made for the H.S.E. skin reaction as specific in acute rheumatism. It is at most an index of previous infection with hæmolytic streptococci.

In our series the incidence of positive reactions among rheumatic cases was similar to that reported by Collis (1932), but in controls the incidence was much higher than in his series. Our early controls were out-patients and patients in medical wards of children's hospitals : these gave figures of the same order as Collis'. Later we gained access to cases (and controls) in an institution in which many patients were convalescent after ear, nose and throat operations. Controls were selected quite impartially from among 
patients presenting no suggestion of rheumatism. A very high proportion of these latter controls reacted, many with some severity. At first we thought that these cases, probably infected with hæmolytic streptococci, should not be used, but it was then realized that to exclude all those with a recent history of hæmolytic streptococcal infection would render the control series quite valueless. Especially would this be the case in view of the probability of transmission from case to control and vice versa within the same ward.

Our results may be summed up by stating that cases of rheumatism revealed rather more evidence of previous infection with the hæmolytic streptococcus than did non-rheumatic controls. The paramount question of what peculiarity exists in the micro-organism or the host to determine acute rheumatism as the resultant of streptococcal infection remains unanswered. The question of why some cases of gonococcal infection have joint involvement, while others have not, appears to be analogous; and in the present state of our knowledge of the interaction of host and micro-organism no explanation is available.

The finding of hæmolytic streptococci in the throats of twice as many cases as controls was of interest. The strains are being further studied. So far we have ample evidence that the micro-organisms isolated are serologically heterogeneous. By a serological study of the strains from cases and controls, obtained simultaneously in the same wards, it will be possible to throw light on the precise significance of the micro-organisms in relation to the disease, since the hæmolytic streptococcus strains recovered from rheumatic fever throats may be simply chance infections subsequent to the onset of the disease and entry into hospital. The finding of the microorganism in a higher proportion of cases than controls may mean no more than that the throat in acute rheumatism is a more favourable nidus for its persistence.

Clinically the two main features were the large percentage of positive skin reactions to H.S.E. among the cases of chorea (90 per cent.), and the comparatively small number of such reactions among the febrile group (Table 9). That this predominance of positive reactions in the chorea group was to a certain degree selective, and not merely an increased reactivity to foreign proteins in general, was shown by the reactions to the streptococcus viridans and the ' gamma' streptococcus extracts which were less than those in the other two groups.

As an aid to diagnosis or prognosis the skin reactions were of little, if any, value. Because one patient gave a strong reaction, while another only a weak one, it was not possible to say either that the prognosis was worse in the one case than in the other, or even that one was a case of rheumatism and the other was not. The only modifying factor in either group was apparently the presence or otherwise of pyrexia and, if present, its duration.

One of the most interesting results of our study has been from the group of rheumatic and control cases which was investigated at the large convalescent hospital mentioned. Here we were able to observe a number of patients with quiescent rheumatism, all showing an intense allergic reaction, in whose throats hæmolytic.streptococci were abundant. Such cases 
appeared to provide all the conditions necessary for relapse, and yet none occurred. It was noteworthy also that in this institution the controls showed more marked allergy than the rheumatic cases elsewhere.

These results suggest strongly that the allergic skin-reaction is an index of the hæmolytic streptococcus factor alone. Infection with this microorganism may be an important factor in the production of the rheumatic state but the intradermal test of allergy is not an indicator of the reactive state in the patient necessary to produce the ' rheumatic' response to such infection.

At the same time our findings adduce no evidence which is contrary to the theory of hæmolytic streptococci as the cause of acute rheumatism. Thus we find that 25 per cent. of cases do not show skin hypersensitiveness to the endo-products of the organism, a finding to which Gibson and McGibbon (1932) showed a parallel after scarlet fever, a disease known to be due to this micro-organism. Again, a high percentage of positive reactions among controls, varying with environment as shown by our Astley Ainslie Institution cases, also means little when the high risk of infection of all with the streptococcus is taken into account. The finding of positive Dick reactions among rheumatics is also of little import, and in no way rules out the possibility of a previous infection with the micro-organism. Apart from the existence of atoxigenic strains it must be remembered that a persistently positive Dick reaction is frequently found even after scarlet fever.

Epidemiological and clinical evidence is strongly in favour of an association between the hæmolytic streptococcus and acute rheumatism. In the absence of a susceptible animal all work must approach the subject indirectly. The presence of cutaneous hypersensitiveness is probably not the crucial index of the reactive state in the patient necessary to produce rheumatism after infection.

\section{Summary.}

1. The intradermal reactions to extract preparations of streptococci of different types have been ascertained.

2. Strongly positive reactions to extract of hæmolytic streptococcus are more common in rheumatic than in control cases.

3. Reactions to viridans and 'gamma' streptococcus extracts show no significant difference as between rheumatic and control series. There is, however, some evidence that the incidence of reactions to extracts of non-hæmolytic streptococci is associated with the degree of sensitivity to antigens of hæmolytic strains.

4. The Dick reaction was positive in 16 per cent. of rheumatic cases as compared with 28 per cent. of controls. Hæmolytic streptococci were isolated from the throats of 43 per cent. of rheumatic cases as compared with 20 per cent. of controls. In neither rheumatic nor control groups could any significant differences in skin reactivity be made out between those who, harboured the micro-organisms and those who did not.

5. The highest proportion of positive skin reactions to the extract of hæmolytic streptococcus was found in cases of chorea. Afebrile cases were 
less hypersensitive, and febrile cases (including those in whom fever had been present within one month preceding the test) were least sensitive.

6. Of 66 cases in which a reliable record could be obtained, 31 gave a history of sore throats, but only 3 cases had had an attack of tonsillitis within two or three weeks of admission to hospital.

7. Our results were in agreement with those of previous workers who have shown that skin sensitiveness increases with age up to 15 years, after which no further increase is noted.

8. The conclusion is reached that the allergic skin reaction may be a result of previous infection with hæmolytic streptococci. The presence of skin hypersensitiveness to intracellular antigens of this micro-organism cannot be regarded as an indication of the special reactivity necessary to produce acute rheumatism on infection.

9. The intradermal reaction does not appear to be of direct diagnostic or prognostic value in cases of rheumatic infection.

It is with pleasure that we acknowledge the cordial co-operation of the numerous physicians in the city who have placed their cases at our disposal.

In particular our thanks are due to Professor McNeil, Dr. Carmichael, Dr. Thatcher and Dr. Finlay of the Royal Hospital for Sick Children; to Professor Ritchie, Professor Murray Lyon and Dr. Eason of the Royal Infirmary; and to Colonel Cunningham and his staff at the Astley Ainslie Institution, Edinburgh.

To Dr. W. R. F. Collis of the Hospital for Sick Children, Great Ormond Street, we owe an especial debt of gratitude for placing at our disposal his results in a similar investigation carried out in London, and for his constant advice and assistance throughout the work.

We also acknowledge the help and interest of Professor T. J. Mackie at whose suggestion this study was initiated. The work was made possible by the financial assistance of the Medical Research Council who have throughout provided personal and expenses grants. One of us (D. S.) has been in receipt of a grant from the Harmsworth Fund for Research on Endocarditis, London.

\section{REFERENGES.}

Birkhaug, K. E., J. Inf. Dis., Chicago, 1927, XL, $54 \hat{9}$.

Coburn, A. F., The Factor of Infection in the Rheumatic State, Baltimore, 1931.

Collis, W. R. F., Lancet, Lond., 1931, i, 1341.

Collis, W. R. F., \& Gray Hill, N., Quarter J. Med., Oxford, 1932, N.S., I, 511.

Collis, W. R. F., \& Sheldon, W., Lancet, Lond., 1932, ii, 1261.

Derick, C. L., \& Fulton, M. N., J. Clin. Invest., Baltimore, 1931, X, 121.

Gibson, H. J., \& McGibbon, J. P., Lancet, Lond., 1932, ii, 729.

Glover, J. A., Ibid., 1930, i, 499.

Irvine-Jones, E., Arch. Int. Med., Chicago, 1928, XLII, 784.

Kaiser, A. D., J. Inf. Dis., Chicago, 1928, XLII, 25.

Lancefield, R. C., J. Exp. Med., N.Y:, 1928, XLVII, 469, 481.

Mackenzie, G. M., \& Hanger, F. M., Jr., J. Immunol., Baltimore, 1927, XIII, 41.

Nicholls, E. E., \& Stainsby, W. J., J. Clin. Invest., Baltimore, 1931, X, 337.

Schlesinger, B., Arch. Dis. Child., Lond., 1930, V, 411.

Sheldon, W., Lancet, Lond., 1931, i, 1337.

Swift, H. E., Wilson, M., \& Todd, E. W., Amer. J. Dis. Child., Chicago, 1929, XXXVII, 98.

Todd, E. W., Brit. J. Exp. Path., Lond., 1932, XIII, 248. 